DOI: $10.2478 /$ lpts-2014-0030

\title{
SCIENTIFIC LABORATORY PLATFORM FOR TESTING THE ELECTRIC VEHICLE EQUIPPED WITH DC DRIVE
}

\author{
V.Brazis $^{1}$, K. Kroics ${ }^{1,2}$, L.Grigans ${ }^{2}$ \\ ${ }^{1}$ Riga Technical University \\ 1 Kalku Str., Riga, LV-1658, LATVIA \\ e-mail: viesturs.brazis@rtu.lv \\ ${ }^{2}$ Institute of Physical Energetics \\ 21 Aizkraukles Str., Riga, LV 1006, LATVIA \\ e-mail: kaselt@inbox.lv
}

\begin{abstract}
The authors present a test platform for the low-power DC electric motor of a traction vehicle or a high-power motor scaled in the traction and braking modes. The load emulator of the traction drive is made using an induction motor controlled by a frequency converter. A microcontroller controls the bi-directional DC/DC converter and sends a speed reference signal to the frequency converter. The test bench is meant for determination of the power consumption by motor in various speed cycles, and will be used to demonstrate the operation of electric vehicle to students and to investigate the charging/discharging strategies of energy sources.
\end{abstract}

Key words: test bench, DC motor, traction drive, electric vehicle.

\section{INTRODUCTION}

The key component for successful engineering studies is hands-on experience. Therefore, a relevant facility should provide real world-scale training of students in the electric vehicle technology. High-power and high-voltage electric transport systems (e.g. mentioned in [1]) are unsafe and inconvenient for educational purposes and scientific research, while scaled test benches are useful in these areas.

Furthermore, on-rail and on-road tests of the vehicle are not always fit to thoroughly test each subsystem. These tests are likely to be done during a later phase, while it is not easy to change too much the configuration of a propulsion system. In order to optimize this configuration and to verify the strategies for control and management of energy sources in an early phase, tests at the subsystem level must be made before those at a vehicle level [2]. Therefore, the research into the hybrid electric vehicle with a DC traction drive has been carried out and the relevant test platform developed. 
Test benches are described in [3] and [4], however, these are based on the solutions that require calculation of the resistance torque measured by a torque meter. For using a DC generator as load $[5,6]$ it is necessary to develop a special electronic device that would provide a proper loading of the generator. In the proposed DC traction drive load simulator a conventional frequency converter can be used together with an AC induction electric motor. To evaluate the resistance forces acting on the vehicle at definite speed and road conditions a coast-down test can be carried out, which is much simpler than calculation of the load torque.

\section{THEORETICAL ANALYSIS OF VEHICLE DYNAMICS}

During the movement of a vehicle the following forces act upon it (Fig. 1): the vehicle gravitational force that induces force $R$ of reaction to the road, which determines the rolling resistance force $F_{R}$ on the wheels, the air resistance force $F_{A}$, and the driving force $F_{D}$. To obtain the equations describing the movement of a vehicle, a simplified dynamic model was adopted [7]. The model is based on the assumption that the vehicle has mass $m$ and equivalent moment of inertia $J_{e q}$ corresponding to those of the driving wheels and all rotating parts kinematically connected to them.

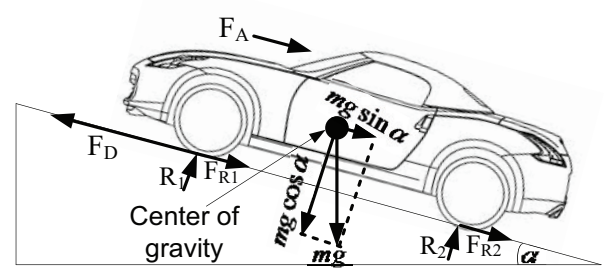

Fig. 1. Forces acting on a vehicle

Mechanical energy of the vehicle consists of kinetic energy $E_{K}$ and potential energy $E_{P}$. The kinetic energy includes the terms relating to the translational mass and to any rotating part connected to the wheels:

$$
E_{K}=\frac{m v^{2}}{2}+\frac{J_{e q} \omega_{w}{ }^{2}}{2}=\frac{m \tau v^{2}}{2}
$$

where $\omega_{w}=v r_{w}$ is the rotation speed of driving wheels, and $\tau=1+\frac{J_{e q}}{m r_{w}^{2}}$ is the coefficient regarding the influence of rotating parts (generally for vehicles it is 1.03 ..1.04 [2] and could be neglected).

To obtain the equation of the vehicle motion, the principle of energy conservation is applied: the derivative of the vehicle mechanical energy is equal to driving power $P_{D}$ minus the total power losses $P_{\text {loss }}$ :

$$
P_{D}-P_{l o s s}=\frac{d E}{d t}=m \frac{d v}{d t}+m g v \sin \alpha
$$


This equation can be rewritten in the following way:

$$
m a=\frac{P_{D}}{v}-\frac{P_{\text {loss }}}{v}-m g \sin \alpha=F_{D}-\left(F_{R}+F_{A}\right)-F_{G},
$$

where $F_{G}=m g \sin \alpha$ is the grade force and $a$ is the acceleration.

By rearranging terms in Eq. (3) we obtain:

$$
a=\left(F_{D}-\left(F_{R}+F_{A}\right)-F_{G}\right) / m .
$$

In the case when a vehicle is coasting, the driving force becomes negative due to the friction in mechanisms (wheel bearings, transmission, differential, etc.). This force is dependent on the speed in a complex way; however, linear components are dominating [8], so the frictional force can be expressed as

$$
-F_{D}=F_{f}=\frac{M_{f}}{r_{w}}=F_{f 0}+F_{f 1} v
$$

where $M_{f}$ is the friction moment applied to the wheels, $F_{f 0}$ is the vehicle resistance at very low speeds, and $F_{f l}$ is the speed-dependent part of resistance.

The formula for computation of the air resistance is:

$$
F_{A}=\frac{1}{2} \rho c_{d} A(v+w)^{2},
$$

where $\rho$ is the air density, $c_{d}$ is the aerodynamic drag coefficient of the motor vehicle; $A$ is the frontal area of the vehicle, and $w$ is the wind velocity in longitudinal direction.

The grade resistance can be calculated by the well-known relation:

$$
F_{G}=m g \sin \alpha,
$$

where $m g$ is the weight of vehicle, and $\alpha$ is the longitudinal slope angle of the road.

In turn, the rolling resistance can be calculated as

$$
F_{R}=m g\left(f_{0}+f_{1} v\right) \cos \alpha,
$$

where $f_{0}$ and $f_{1}$ are constants, $f_{0}$ varies with respect to the road condition, and $f_{1}$ depends on tires.

Inserting Eqs. (5-8) into Eq. (4) we obtain the expression of the vehicle deceleration during coasting as a function of speed:

$$
-a=\left(m g\left(f_{0}+f_{1} v\right) \cos \alpha+m g \sin \alpha+\frac{1}{2} \rho c_{d} A\left(v+w^{2}\right)+F_{F 0}+F_{F 1} v\right) / m=C_{0}+C_{1} v+C_{2} v^{2}
$$

The coefficients of quadratic function from Eq. (9) can be expressed as 


$$
\begin{aligned}
& C_{0}=\left(m g\left(f_{0} \cos \alpha+\sin \alpha\right)+\frac{1}{2} \rho c_{d} A w^{2}+R_{f 0}\right) / m, \\
& C_{1}=\left(m g f_{1} \cos \alpha+\frac{1}{2} \rho c_{d} A w+R_{f 1}\right) / m, \\
& C_{2}=\left(\frac{1}{2} \rho c_{d} A\right) / m .
\end{aligned}
$$

Unknown constants $C_{0}, C_{p}, C_{2}$ can be estimated using experimental methods or computer programs. However, the simplest way to determine them is the so-called coast-down test, which consists in launching a motor vehicle from a definite speed with the engine disengaged, and registering the current speed and distance during the free rolling until the vehicle stops. The test procedure is described in [9]; to obtain the data on the vehicle kinematics during the test, various data acquisition systems can be used - accelerometers, time-speed-distance recorders or the GPS system.

After the coefficients have been obtained, we can calculate the resistance momentum:

$$
M_{R}=F_{R} r_{w}=-m a r_{w}=m r_{w}\left(C_{0}+C_{1} v+C_{2} v^{2}\right) .
$$

This momentum will be used further as the load one in a load simulator system.

\section{TEST BENCH SCHEME AND PARAMETERS}

The test bench (shown in Fig. 2) contains a DC motor that simulates the electric vehicle traction drive and an $\mathrm{AC}$ induction motor simulating the traction drive load. The traction motor is connected to the energy storage that provides DC voltage through a two-quadrant/bi-directional digitally controlled DC/DC converter which allows simulation of the traction and regeneration braking modes without reversing the direction of rotation.

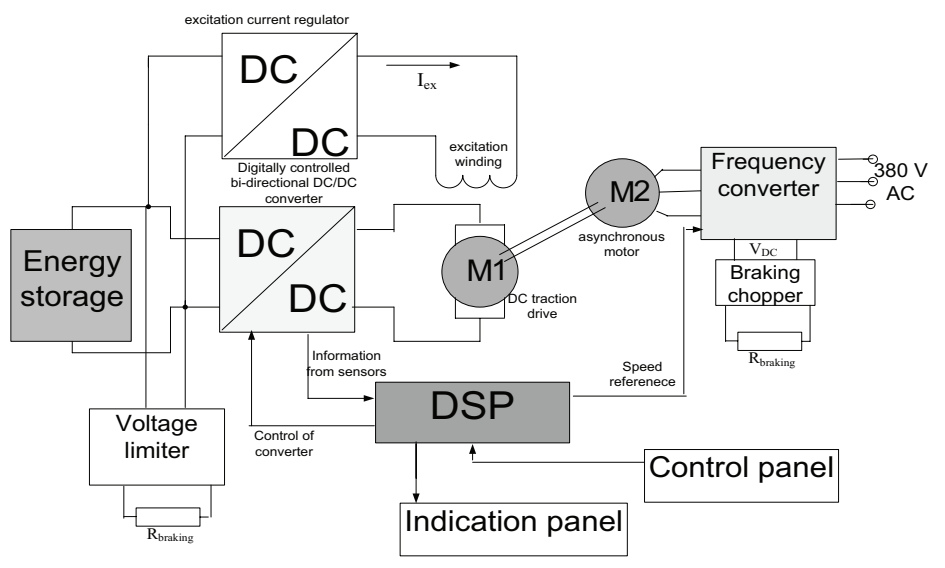

Fig. 2. Schematic of the scientific laboratory platform. 
The load simulator of the vehicle traction drive is built applying the induction motor with a field-oriented control frequency converter and a braking circuit containing a chopper-controlled braking resistor. The AC drive motor generates the opposite load torque. Figure 3 shows implementation of the digitally-controlled test bench (platform) for DC drive.

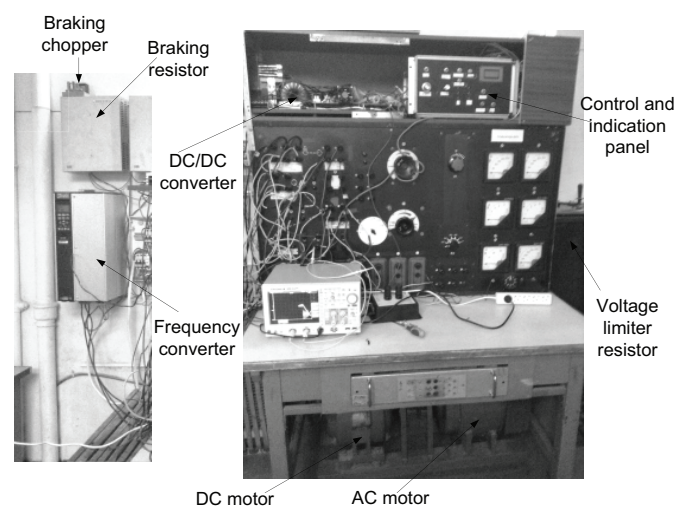

Fig. 3. The scientific platform for testing DC drive of electric vehicle.

The frequency converter shown in Fig. 3 is connected to the $380 \mathrm{~V} / 50 \mathrm{~Hz}$ network. When the DC motor is operating in the drive mode, the AC drive operates in the braking mode as load, with the braking energy produced by the load simulator transferred to the braking resistor. In the braking mode of the traction drive model, the load simulator works in the motor mode. The control system of the load simulator is designed to work in the speed control mode.

The DC motor used in the test bench has the following parameters:

$P_{\text {nom }}=3.7 \mathrm{~kW}$ is the rated power of the motor;

$r_{a}=0.46 \Omega$ is the resistance of armature circuit;

$n_{\text {nom }}=1370 \mathrm{rpm}$ is the rated speed of motor;

$C_{E}=0.6366$ is the electromagnetic constant of motor.

The AC motor is connected to the output of FC300 type Danfoss frequency converter and has the following parameters:

$n_{A C}=1450 \mathrm{rpm}$ is the rated speed of motor;

$V_{A C}=380 \mathrm{~V}, f=50 \mathrm{~Hz}$ are the rated voltage and frequency;

$P_{A C}=4 \mathrm{~kW}$ is the rated power of motor.

The excitation DC/DC converter is made using a typical pulse width modulation integral circuit and regulates the excitation current with respect to the set reference value.

In order to control the DC-DC converter and to send the reference value to the frequency converter the STM32F407VGT6 microcontroller (MCU) is used. To measure the signals, a YOKOGAVA digital oscilloscope was employed. The buttons, potentiometers, LEDs and LCD display provide the user interface. 


\section{LOAD SIMULATOR}

The torque of DC motor at the rated excitation current can be written as [10]

$$
M_{D C}=C_{E} I_{D C}
$$

The task for the control system of load simulator is to control the frequency converter so that the $\mathrm{AC}$ motor acts like a rotating object with a very high moment of inertia $J_{e q}$ and with equivalent mechanical load torque $M_{e q}$. The desirable behaviour of the mechanical system is described by the equation [11]:

$$
\frac{d \omega}{d t}=\frac{C_{E} I_{D C}-M_{e q}}{J_{e q}},
$$

where $C_{E}$ is an electromagnetic constant of DC motor;

$I_{D C}$ is the current of DC motor;

$M_{e q}$ is the equivalent momentum of resistance.

The expression for the reference angular speed of frequency converter could be obtained by integration of Eq. (15):

$$
\omega=\frac{1}{J_{e q}} \int\left(C_{E} I_{D C}-M_{e q}\right) d t
$$

In compliance with Eq. (16), the controller of load simulator can be built as shown in Fig. 4.

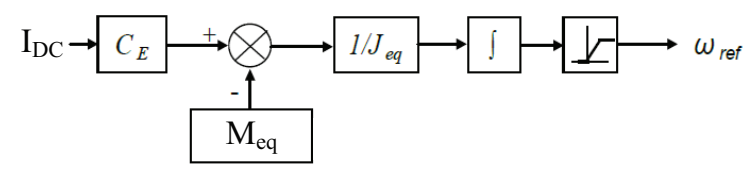

Fig. 4. Control algorithm of the simulator.

If the current of DC drive is greater than zero $\left(I_{D C}>0\right)$ the system provides acceleration, while at $I_{D C}<0$ the $\omega_{\text {ref }}$ value decreases and the system decelerates, thus imitating the braking mode. The integrator is equipped with a limiter to provide the limits $0<\omega_{\text {ref }}<\omega_{\text {ref.max }}$ and to avoid the reverse of rotational direction after braking.

To simulate the operation of a real electric vehicle, the scale adjustment is to be done. Assuming that the time scale is $1: 1$ and that the rated speed of motor corresponds to the linear speed of vehicle at a rated motor speed, the equivalent moment of inertia is calculated as

$$
J_{e q}=\frac{r_{w}^{2} K_{\omega}^{2}}{16 K_{\text {gear }}^{2} K_{P}} m
$$

where

$$
K_{\omega}=\frac{\text { vehicle_rated_speed }}{\text { bench_rated_speed }} \text { is the speed scale factor; }
$$


$K_{\text {gear }}$ is the vehicle gear box ratio;

$K_{P}$ is the power scale factor.

The equivalent moment of resistance can be calculated as

$$
M_{e q}=\frac{M_{R} K_{\omega}}{K_{\text {gear }} K_{P}} .
$$

The algorithm shown in Fig. 4 was implemented by using the microcontroller. The current of DC traction drive is bi-directional; therefore, to measure it a Hall effect current sensor was selected. The speed reference signal is calculated in the digital form; using a digital-to-analog converter it is converted to the analog voltage value, which is then amplified by the operational amplifier. Finally, the amplified voltage is obtained as speed reference of the frequency converter.

To control the DC motor, a DC-DC bi-directional converter was developed, which operates in both the buck and the boost modes. To reduce the conduction losses, the transistors operate in both the forward and the reverse conduction modes. The transistors are controlled digitally by pulse width modulation. The switching frequency of the converter is $20 \mathrm{kHz}$.

Figure 5 exemplifies a tramcar with simulated DC electric drive. The factors for scaling the load simulator are given in [12]. The tramcar Tatra T3M has the following parameters:

$r_{w}=0.35 \mathrm{~m}$ is the wheel radius;

$m=18.5 \mathrm{t}$ is the mass of empty tramcar;

$k_{\text {gear }}=7.36$ is the vehicle gear box ratio;

$n_{\text {tram nom }}=1720 \mathrm{rpm}$ is the rated speed of motor;

$P_{\text {tram, nom }}=180 \mathrm{~kW}$ is the rated power of all the motors of tramcar.

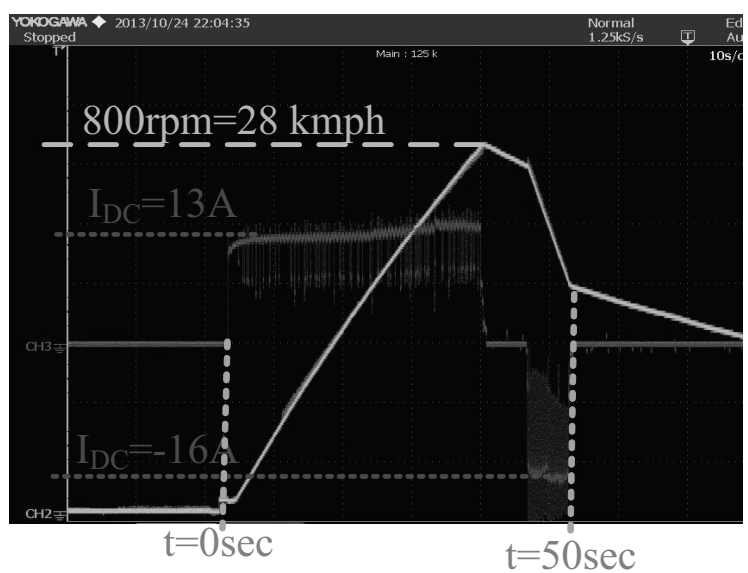

Fig. 5. The current of DC drive and the speed reference signal.

At scaling taken into account, the experimental results coincide with the graph of a real tram. The test bench that simulates the operation of tram is very useful for testing the ultracapacitor-based braking energy recovery system. Although the platform has a lower power as compared with the real tram, the charging/discharging strategies of the energy storage and the topology of DC-DC converter can be tested very successfully. 


\section{CONCLUSIONS}

The experimental model of the DC traction drive load simulator shows that such a simulator can be built using an AC induction motor together with a frequency converter. Proper operation of the relevant test bench depends on the correct scaling.

The speed control mode has the advantage of the drive performance being independent of the load resistance torque fluctuations. The digital control of such a system makes easy its configuration and is flexible.

The test bench is useful for students, enabling them to conduct research and to test the electric vehicle at early stages. The use of the proposed platform makes it possible to study the systems for recovering the regenerative braking energy.

\section{ACKNOWLEDGEMENT}

The paper is supported by the Project by the Riga Technical University through the Scientific Research Project Competition for Young Researchers No. ZP-2012/21.

\section{REFERENCES}

1. Alcala, I., Claudio, A., \& Guerrero, G. (2008). Test bench to emulate an electric vehicle through equivalent inertia and machine dc. The $11^{\text {th }}$ IEEE International Power Electronics Congress. Cuernavaca, 198-203.

2. Chan, C. C., \& Chau, K. T. (2001). Modern Electric Vehicle Technology. New York: Oxford University Press.

3. Drabek, P., Streit, L., \& Los, M. (2010). The energy storage system with supercapacitor. The $14^{\text {th }}$ International Power Electronics and Motion Control Conference. Ohrid (Macedonia), 39-43.

4. Iannuzzi, D. (2008) Improvement of the energy recovery of traction electrical drives using supercapacitors. The $13^{\text {th }}$ International Power Electronics and Motion Control Conference, 1492-1497.

5. Lungoci, C., \& Bouquain, D. (2008). Modular test bench for a hybrid electric vehicle with multiple energy sources. The $11^{\text {th }}$ International Conf. OPTIM 2008. Transilvania, 299-306.

6. Tur, O., et al. (2007). Sizing, design and prototyping of an electric drive system for a split drive hybrid electric vehicle. The IEEE International Conf. IEMDC 2007. Antalia, 1745-1750.

7. Fajri, P., Ahmadi, R., \& Ferdowsi, M. (2012). Equivalent vehicle rotational inertia used for electric vehicle test bench dynamic studies. The International Conf. IECON 2012, 4115 4120 .

8. Takagi, H. (2005). Real-life coefficient of drag - a simple extraction method. Auto Technology, (4), 52-53.

9. Preda, I., Covaciu, D., \& Ciolan, G. (2010). Coast-down test - theoretical and experimental approach. The International Conf. CONAT2010. Brasov, 155-162.

10. Leonhard, W. (1996). Control of Electrical Drives. New York: Springer Verlag. 
11. Brazis, V., Zaleskis, G., Latkovskis, L., \& Grigans, L. (2011). Traction drive load simulator. The International Conf. of Riga Technical University. Riga, 68-69.

12. Zaleskis, G., Brazis, V., \& Latkovskis, L. (2012). Estimation of traction drive test bench with energy storage system operation in regenerative braking mode. Electrical, Control and Communication Engineering, (1), 40-45.

\title{
LABARATORIJAS ZINĀTNISKĀ PLATFORMA AR LİDZSTRĀVAS MOTORU APRĪKOTU ELEKTRISKO AUTOMOBĪḶU TESTËŠANAI
}

\author{
V. Bražis, K. Kroičs, L. Grigāns
}

K ops a vi $1 \mathrm{ku} \mathrm{m} \mathrm{s}$

Šajā rakstā piedāvāta testa platforma ar līdzstrāvas motoru aprīkotu elektrisko transportlīdzekḷu vilces un bremzēšanas režīmiem. To ir lietderīgi izmantot, lai noteiktu motora energíjas patēriņu dažādos režīmos, lai pētītu akumulatoru baterijas izlādes stratēǵijas, lai izstrādātu pārveidotājus motora vadībai kā arī rekuperatīvās bremzēšanas enerǵijas uzkrāšanas sistēmas. Slodzes emulators ir izveidots, izmantojot asinhrono motoru ar īsslēgtu rotoru un industriālo frekvenču pārveidotāju. Stenda vadībai ir izmantots mikrokontrolers, kas aprēķiniem izmanto rakstā apskatītās teorētiskās formulas.

22.09.2014. 